\title{
Model OF A Linear Motor Mechanical LoAD
}

\author{
Martin Pustka ${ }^{1}$ Z Zdeněk Braier \\ VÚTS, a.s., Measurement Department, \\ Svárovská 619, Liberec XI - Růžodol I, 46001 Liberec, Czech Republic \\ e-mail: ${ }^{1}$ martin.pustka@vuts.cz
}

\begin{abstract}
The residual vibrations originating from a finite stiffness of the motion control system influence the positioning accuracy of machine working members. This paper deals with the dynamic behavior modelling of a motor load composed of seismic mass supported by two flat springs. Two linear models presented in the paper comprise a continuous model based on the prismatic beam bending vibration theory with appropriated boundary conditions and a discrete model with lumped parameters and a single degree of freedom. Both models were used to simulate the motion of oscillating system with various displacement laws and the results were compared with experimental data measured on a real system.
\end{abstract}

\section{Keywords}

Mechanical vibration; Equivalent model; Damping; Frequency response; Time response.

\section{Introduction}

The production machines and machine tools with linear drives produce residual vibrations, which unfavorably influence the positioning accuracy of working members. The spurious vibrations originate from a finite stiffness of the linear motor-working member system. To increase the positioning accuracy special control methods as input shaping, load model (SEM) or controllers with inverse dynamics are employed [1].

The thesis [2] introduces a theoretical and experimental analysis of linear motor loaded on its output by a flexibly mounted mass. The secondary load system consists of a seismic mass $m$ supported by two flat steel springs with rectangular cross-section $b_{0} \times h$ and length $L$ (Fig. 1). The mass $m$ can move only in the direction of motor slider without rotation about a normal axis.
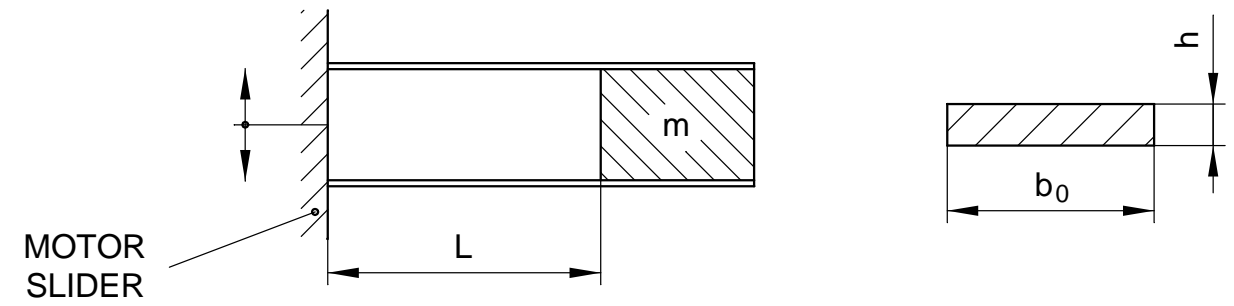

Source: Own

Fig. 1: Design of dynamic mechanical load system (left), flat spring cross-section (right)

This mechanical load system was used to verify various control algorithms and methods for measurement and evaluation of motor and mass kinematic quantities. One of the problems was the substitution of the secondary oscillating system by a suitable mechanical model and its control circuit implementation. Several simple models were successively created, in this paper two possible methods of linear modelling by means of a distributed parameter system 
and a single mass system with lumped parameters are presented. Two parallel springs are substituted by one spring with a thickness $b=2 b_{0}$. The calculated frequency response functions and time responses are compared with experimental data.

\section{$1 \quad$ Distributed Parameter Model (Continuous Model)}

The flexible mounted mass is modelled as a laterally vibrating cantilever beam with a discrete mass at the free end (Fig. 2). The system is excited by a base motion of the clamped end [3].

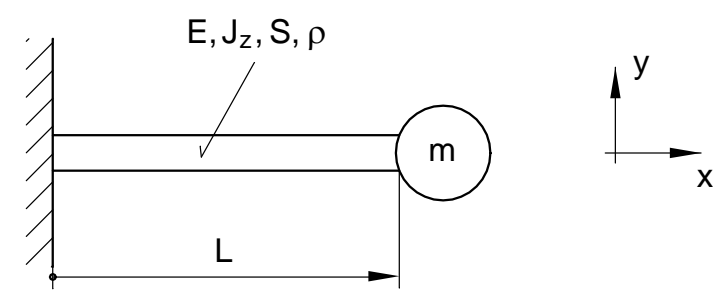

Source: Own

Fig. 2: Distributed parameter model

The general equation of motion for the lateral vibration of a uniform beam is [4]

$$
\frac{\partial^{2} y}{\partial t^{2}}+\frac{E J_{Z}}{\rho S} \frac{\partial^{4} y}{\partial x^{4}}=0
$$

where $E$ is the Young's modulus, $J_{Z}=\frac{b h^{3}}{12}$ is the area moment of inertia of the beam crosssection, $\rho$ the density and $S=b h$ is the cross-section area. We consider the steady-state solution in the form

$$
y(x, t)=\left[C_{1} \cosh \beta x+C_{2} \sinh \beta x+C_{3} \cos \beta x+C_{4} \sin \beta x\right] e^{\mathrm{j} \omega t}=y(x) e^{\mathrm{j} \omega t},
$$

where $C_{i}$ are unknown amplitudes, $\omega$ is angular frequency and $\beta$ is normalized frequency. The system is excited by a harmonic displacement $y_{0} e^{\mathrm{j} \omega t}$ at the clamped end $x=0$, the rigid mass $m$ moves in direction $y$ without rotation at the free end $x=L$. The boundary conditions have then a form

$$
y(0)=y_{0}, \frac{\partial y}{\partial x}(0)=0, \frac{\partial y}{\partial x}(L)=0, \frac{\partial^{3} y}{\partial x^{3}}(L)=-\frac{\omega^{2} m}{E J_{Z}} y(L)
$$

Substituting the solution (2) into boundary conditions (3) we obtain the relations for unknown coefficients $C_{i}$

$$
\begin{gathered}
C_{1}=\frac{y_{0}}{2} \frac{1-\cosh \beta L \cos \beta L-\sinh \beta L \sin \beta L-\frac{2 \rho S L}{\beta L m} \cosh \beta L \sin \beta L}{1-\cosh \beta L \cos \beta L-\frac{1 \rho S L}{\beta L}(\cosh \beta L \sin \beta L+\cos \beta L \sinh \beta L)}, \\
C_{2}=\frac{y_{0}}{2} \frac{\cosh \beta L \sin \beta L+\cos \beta L \sinh \beta L+\frac{2 \rho S L}{\beta L} \sinh \beta L \sin \beta L}{1-\cosh \beta L \cos \beta L-\frac{1 \rho S L}{\beta L}(\cosh \beta L \sin \beta L+\cos \beta L \sinh \beta L)}, \\
C_{3}=-C_{1}+y_{0}, C_{4}=-C_{2} .
\end{gathered}
$$

The denominator in expressions (4) is the frequency equation (5)

$$
1-\cosh \beta L \cos \beta L-\frac{1}{\beta L} \frac{\rho S L}{m}(\cosh \beta L \sin \beta L+\cos \beta L \sinh \beta L)=0
$$


with roots $\beta L$. The eigenfrequencies of bending vibration can easily be obtained from equation

$$
f_{01}=\frac{(\beta L)^{2}}{2 \pi L^{2}} \sqrt{\frac{E J_{Z}}{\rho S}}
$$

The frequency response function of the system (a ratio between displacements at the free and clamped end) is calculated from Eqs. (2) and (4) as

$$
H(\omega)=\frac{y(L)}{y_{0}}(\omega)
$$

Using the inverse Fourier transform we get the impulse response function $h(t)=$ $\mathrm{FFT}^{-1} H(\omega)$. The displacement at the free end is defined by a convolution of base motion $y(0, t)$ and impulse function $h(t)$

$$
y(L, t)=y(0, t) * h(t) .
$$

\section{Lumped Parameter Model (Discrete Model)}

The flexible mounted mass is approximated by a discrete mass-spring-damper system (Fig. 3). This system is excited by a base motion $y_{1}$ and has a single degree of freedom.

Source: Own

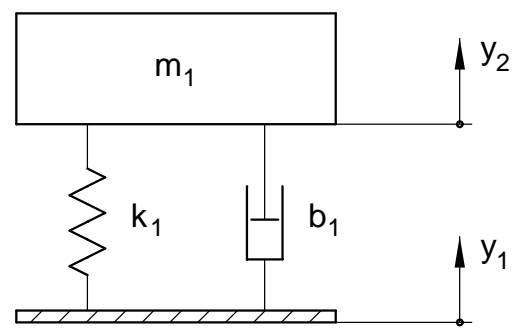

Fig. 3: Lumped parameter model

The equation of motion of a system excited through elastic support is

$$
m_{1} \ddot{y}_{2}(t)+b_{1} \dot{y}_{2}(t)+k_{1} y_{2}(t)=b_{1} \dot{y}_{1}(t)+k_{1} y_{1}(t)
$$

and model parameters are given by [4]

$$
m_{1}=m+m_{\mathrm{R}}, k_{1}=\frac{12 E J_{Z}}{L^{3}}, b_{1}=2 \xi \sqrt{m_{1} k_{1}}
$$

where $m_{\mathrm{R}}=\frac{13}{35} \rho S L$ is the reduced mass of flat spring and $\xi$ is the viscous damping ratio. The system eigenfrequency is expressed as

$$
f_{02}=\frac{1}{2 \pi} \sqrt{\frac{k_{1}}{m_{1}}}
$$

The frequency response function $H(\omega)$ can be obtained by substituting $y_{i}(t)=y_{i} e^{\mathrm{j} \omega t}$ for $y_{i}$ into Eq. (9). The displacement time course $y_{2}(t)$ is a solution of wave equation (9) with exciting waveform $y_{1}(t)$ and its derivative $\dot{y}_{1}(t)$ on the right-hand side. 


\section{$3 \quad$ Simulation Results}

The theoretical models were used to simulate the seismic mass motion excited by motor slider. The calculation was carried out using real values of mass $m=0.56 \mathrm{~kg}$, supported by two flat steel springs of length $L=0.04 \mathrm{~m}$ and cross-section area $b_{0} \times h=25 \times 0.4 \mathrm{~mm}^{2}$. The system eigenfrequency $f_{m}=17.5 \mathrm{~Hz}$ and the viscous damping ratio $\xi=0.005$ were determined from measured transient vibration excited by a force pulse [5]. As the spring mounting at both ends is not perfectly stiff, the constants $E$ and $k_{1}$ were substituted by effective values $E^{*}$ and $k_{1}^{\prime}$,

$$
E^{*}=E(1+\mathrm{j} \eta)\left(\frac{f_{m}}{f_{01}}\right)^{2}, k_{1}^{\prime}=k_{1}\left(\frac{f_{m}}{f_{02}}\right)^{2}
$$

where the original eigenfrequencies $f_{01}, f_{02}$ are given by (6) and (11) and $\eta=2 \xi$ is the hysteretic damping loss factor. The model viscoelastic behavior is described by the complex Young's modulus $E^{*}$.

Fig. 4 shows the frequency response function of the continuous model calculated using Eq. (7). The maximum of amplitude characteristics corresponds to the lowest bending eigenfrequency. The frequency response function of the discrete model calculated using Eq. (9) is virtually identical in the given frequency range.

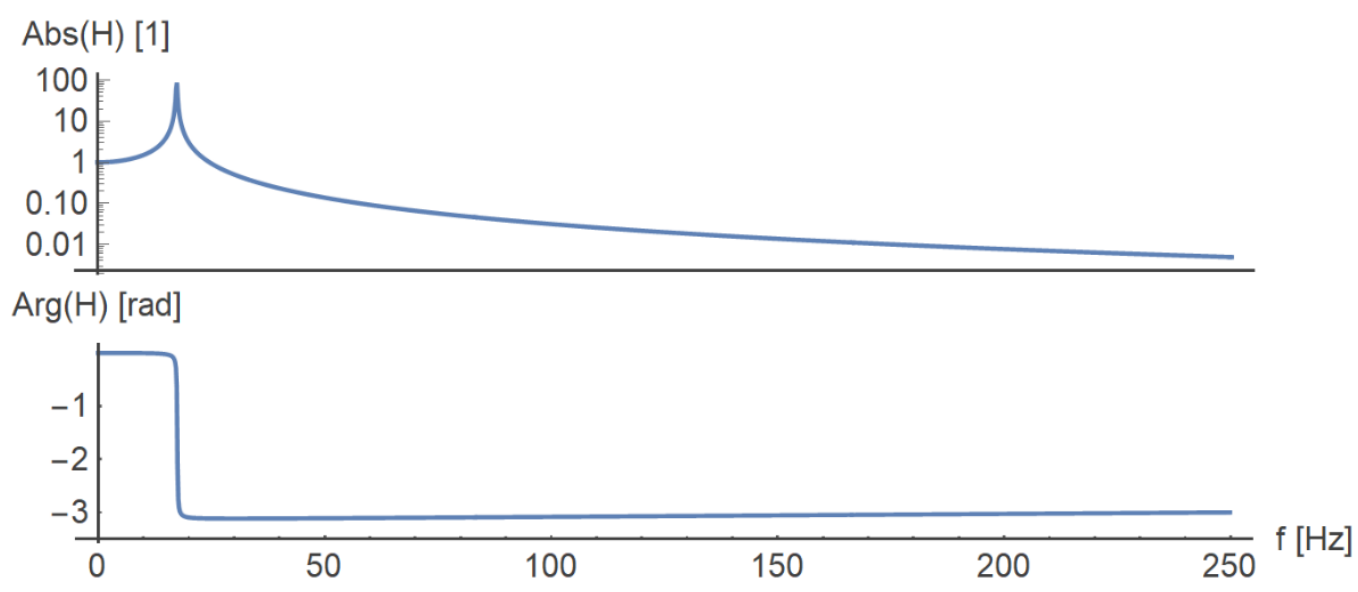

Source: Own

Fig. 4: Frequency response function of the oscillating system

The time response of oscillating system was successively assessed for various motor displacement laws. Fig. 5 (top) depicts an example of three periods of measured slider displacement $y(0, t)$, which corresponds to the displacement law labeled F1. The seismic mass displacement $y(L, t)$ calculated using Eq. (8) is shown in Fig. 5 (bottom).

The assessment of oscillating system vibrations from diagrams shown in Fig. 5 is not illustrative. Therefore, the relative seismic mass displacement with respect to slider displacement $\Delta y=y(L)-y(0)$ was further evaluated. Fig. 6 depicts the relative displacements of continuous (steady-state) model (top), of discrete model $\left(\Delta y=y_{2}-y_{1}\right)$ (middle) and the measured course for comparison (bottom). The response of the continuous model calculated using convolution (8) has three periods of steady-state vibrations, the solution of the discrete model from Eq. (9) includes also the initial transient state. After the transient motion disappears (approximately from the third period) the results of both models are in good agreement as is clear from Fig. 7. 


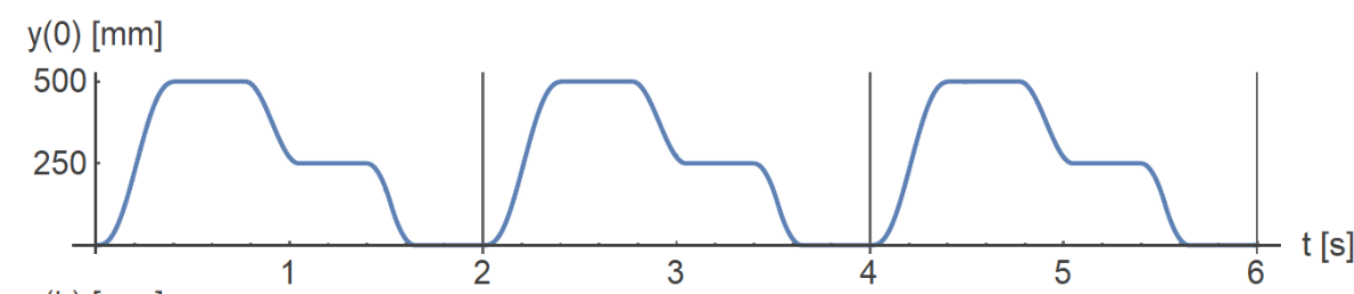

$\mathrm{y}(\mathrm{L})[\mathrm{mm}]$

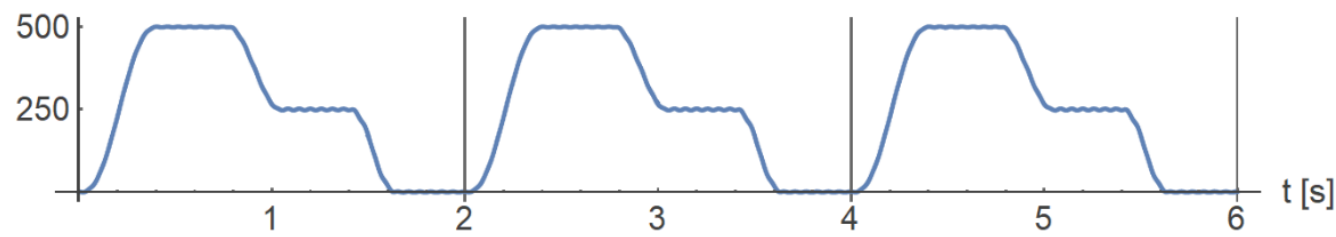

Source: Own

Fig. 5: Measured motor slider displacement (top) and calculated displacement of oscillating system (bottom) for displacement law F1

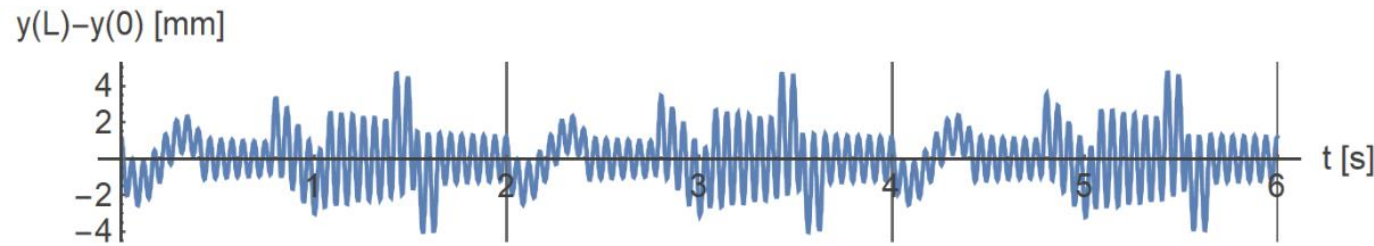

$y_{2}-y_{1}[\mathrm{~mm}]$

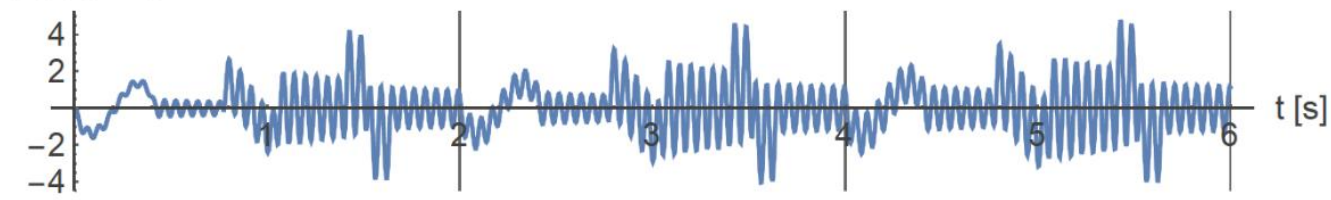

$\Delta \mathrm{y}_{m}[\mathrm{~mm}]$

Source: Own

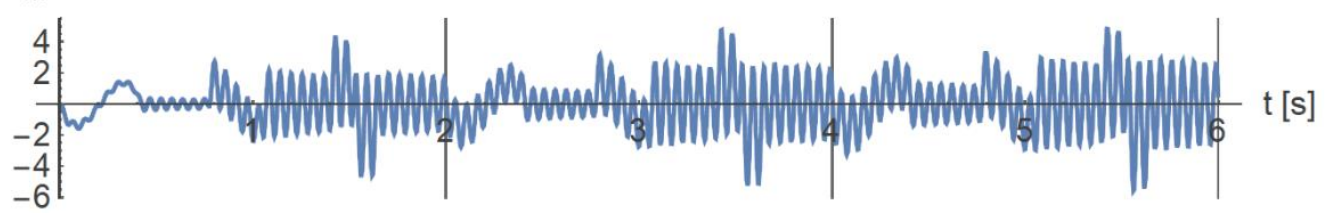

Fig. 6: Relative displacement of oscillating system (top - continuous model, middle discrete model, bottom - measured time course)

$\Delta[\mathrm{mm}]$

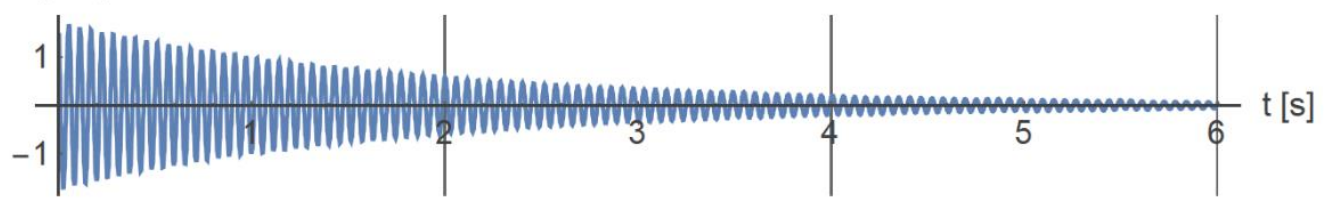

Source: Own

Fig. 7: Difference of relative displacements $\Delta y$ of continuous and discrete model

The comparison of one period of continuous model steady-state vibrations (red) with measured time course (green) is shown in Fig. 8. The theoretical time course fairly coincides with measurement, only in the last part of the cycle (motor at standstill) the calculated vibrations have approximately half amplitude. The main reason for this difference are phase shifts of summands in relative displacement. 


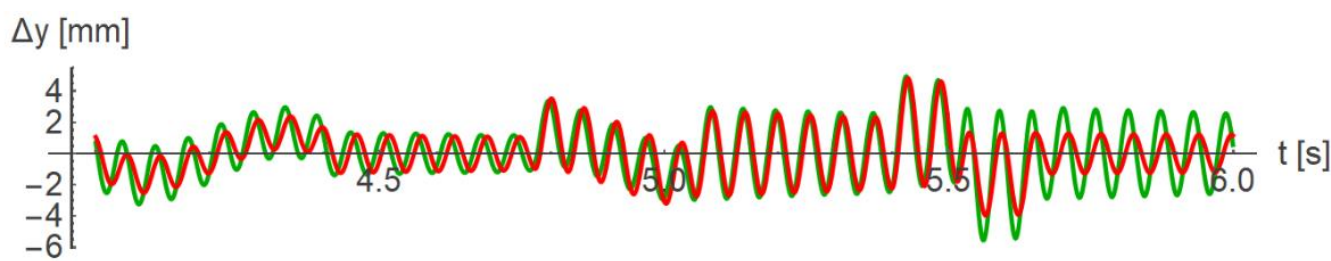

Source: Own

Fig. 8: Relative displacement of oscillating system (red-discrete model, green-measured time course)

\section{Conclusion}

Several linear models of oscillating system were created within the design process of control algorithm for linear motor loaded on its output by flexibly mounted mass. In the paper the continuous model based on the prismatic beam bending vibration theory and the discrete lumped parameter model with a single degree of freedom were introduced.

Both models were used to simulate the motion of oscillating system with various displacement laws and the results were compared with experimental data. The differences between model results and measured values are small in terms of control requirements. After model implementation into control algorithm and using the input shaping method almost two orders of magnitude suppression of unwanted vibrations was achieved [6].

\section{Acknowledgements}

This work was supported by the Czech Ministry of Industry and Trade in the framework of the institutional support for long-term conceptual development of research organization recipient VÚTS, a.s.

\section{Literature}

[1] JIRÁSKO, P. et al.: Special mechanisms and their drives. Part III. VÚTS, a.s., Liberec, 2018. ISBN 978-80-87184-86-8.

[2] BRAIER, Z.: Analýza chování a měrení lineárního motoru s dynamicky uloženou kmitající hmotou na pružinách. Ph.D. Thesis. Faculty of Mechatronics, Informatics and Interdisciplinary Studies, Technical University of Liberec, 2019.

[3] PUSTKA, M.; ERHART, J.; MOKRÝ, P.: Vibration control using piezoelectric bimorphs connected to negative capacitance circuits. Advances in Applied Ceramics. 2010, Vol. 109, Issue 3, pp. 180-183. DOI: 10.1179/174367509X12447975734113

[4] BREPTA, R.; PŮST, L.; TUREK, F.: Mechanické kmitání. Sobotáles, Praha, 1994. ISBN 80-901684-8-5.

[5] EWINS, D. J.: Modal Testing: Theory, Practice and Application. Research Studies Press, Baldock, 2000. ISBN-10: 0863802184. ISBN-13: 9780863802188.

[6] BRAIER, Z.; ŠIDLOF, P.; FIŠER, P.: Measurement, evaluation and comparison of positioning accuracy and other SGT linear motor quantities. In: $14^{\text {th }}$ International Conference Mechatronic Systems and Materials MSM 2018. AIP, 2018. DOI: $\underline{10.1063 / 1.5066470}$ 


\section{MODEL MECHANICKÉ ZÁTĚŽE LINEÁRNÍHO MOTORU}

Residuální kmitání způsobené poddajnostmi v soustavě lineárního pohonu a zátěže ovlivňuje přesnost výsledné polohy pracovního členu. Článek se zabývá modelováním dynamického chování zátěže tvořené seismickou hmotou uloženou na dvou plochých pružinách. Uvedeny jsou dva lineární modely - spojitý model odvozený na základě teorie ohybových kmitů prizmatického nosníku s odpovídajícími okrajovými podmínkami a diskrétní model se soustředěnými prvky o jednom stupni volnosti. Oba modely byly použity k simulaci pohybu připojené soustavy pro různé průběhy zdvihových funkcí motoru a porovnány s průběhy naměřenými na reálné soustavě.

\section{MODELL DER MECHANISCHEN BELASTUNG DES LINEARMOTORS}

Die Residualschwingungen, die von einer im System des Linearmotors und der Belastung auftretenden Nachgiebigkeit verursacht werden, beeinflussen die Zielpositionsgenauigkeit des Arbeitsglieds. Der Artikel befasst sich mit der Modellierung des dynamischen Motorverhaltens bei einer Belastung, die von einer über zwei Blattfedern gelagerten seismischen Masse erzeugt wird. Es werden zwei Linearmodelle angegeben, ein kontinuierliches Modell, das auf der Basis der Biegeschwingungstheorie vom prismatischen Balken mit entsprechender Randbedingungen abgeleitet ist, und ein diskretes Modell mit konzentrierten Parametern und einem Spielraumgrad. Beide Modelle wurden für eine Simulation der Strukturbewegung bei verschiedenen Motorbewegungsgesetzen verwendet und mit den auf dem realen System gemessenen Verläufen verglichen.

\section{MODEL MECHANICZNEJ WYTRZYMAŁOŚCI SILNIKA LINIOWEGO}

Drgania resztkowe spowodowane sztywnością układu napędu liniowego oraz obciążenia wpływają na dokładność ostatecznego położenia elementu roboczego. Artykuł poświęcony jest modelowaniu dynamicznego zachowania pod obciążeniem tworzonym przez masę sejsmiczną ułożoną na dwóch płaskich sprężynach. Przedstawiono dwa modele liniowe model ciągły opracowany na podstawie teorii drgań zginających pręta pryzmatycznego z odpowiednimi warunkami skrajnymi oraz model dyskretny ze skupionymi elementami o jednym stopniu swobody. Oba modele zostaną wykorzystane do symulacji ruchu przyłączonego układu dla różnych przebiegów funkcji skokowej silnika oraz porównane z przebiegami zmierzonymi na rzeczywistym układzie. 